\title{
Performance and meat quality of Nordic Red and Aberdeen Angus bulls offered faba bean or field pea based whole crop legume- cereal silages
}

\author{
Arto Huuskonen ${ }^{1}$, Maiju Pesonen ${ }^{1}$ and Markku Honkavaara ${ }^{2}$ \\ ${ }^{1}$ Natural Resources Institute Finland (Luke), Green Technology, Tutkimusasemantie 15, Fl-92400 Ruukki, Finland \\ ${ }^{2}$ Natural Resources Institute Finland (Luke), New Business Opportunities, Humppilantie, FI-31600 Jokioinen, Finland \\ e-mail: arto.huuskonen@luke.fi
}

\begin{abstract}
The objective of this study was to determine the effects of silage plant species (faba bean and field pea based whole crop legume-cereals vs. grass) on performance and meat quality of growing Aberdeen Angus (AA) and Nordic Red (NR) bulls. A $2 \times 3$ factorial design was used. The experiment comprised 30 AA and 30 NR bulls. Both breeds were randomly allotted to the three feeding treatments. The compositions ( $\mathrm{g} \mathrm{kg}^{-1} \mathrm{dry}$ matter) of diets were: 1 ) grass silage (650) plus rolled barley (350), 2) faba bean-wheat silage (650) plus rolled barley (350) and 3) pea-wheat silage (650) plus rolled barley (350). The experimental diets were offered as total mixed rations ad libitum. The AA bulls grew faster, had better feed conversion rates and superior dressing proportion and carcass conformation compared to the NR bulls. Replacing grass silage by whole crop legume-cereal silages in the diet did not have remarkable effects on animal performance, carcass characteristics or meat quality.
\end{abstract}

Key words: beef production, pea, faba bean, growth, carcass characteristics, eating quality, meat fatty acids

\section{Introduction}

Beef production in Finland is mostly based on the dairy breeds, and Nordic Red (NR) and Holstein are the two most frequently used breeds (Niemi and Ahlstedt 2014). However, the decrease in the dairy cattle population observed in recent years threatened to reduce the level of beef production, and production from beef breed calves is increasing at present. In total, 12 beef breeds are currently kept in Finland, and Aberdeen Angus (AA), Blonde d'Aquitaine, Charolais, Hereford (HF), Limousin and Simmental are the six most frequently used breeds (Pesonen and Huuskonen 2015). When growing and finishing cattle are reared under EU organic farming regulations (CEC 1999), diet should contain forage at least $600 \mathrm{~g} \mathrm{~kg}^{-1}$ dry matter (DM). Consequently, earlier maturing British breeds (AA, HF), which perform well on moderate nutrition (Phillips 2010), are most commonly used beef breeds in organic farming systems in Finland.

Most of the forage for growing cattle in Nordic countries is based on silage mixtures of different grasses (timothy [Phleum pratense], meadow fescue [Festuca pratensis], tall fescue [Festuca arundinacea]) and red clover (Trifolium pratense) but other ensiled forages, such as different whole crop silages, are increasingly being used due to their potentially lower costs (Huuskonen 2013). In Finland, barley (Hordeum vulgare), oats (Avena sativa) and wheat (Triticum aestivum) are the dominant small-grain species utilized for whole crop production (Huuskonen 2013). Producing whole crop small grain cereal silages provides an opportunity to improve the efficiency of forage production for ruminants under Northern European conditions (Wallsten 2008, Rustas 2009).

Especially in organic farming systems, annual legumes are often sown with cereals. In Nordic countries faba bean (Vicia faba), field pea (Pisum sativum), common vetch (Vicia sativa) and hairy vetch (Vicia villosa) are commonly used annual legumes. Intercropping of annual legumes and cereals can provide numerous benefits to the cropping system through increasing total yield and land use efficiency, improving yield stability, enhancing light, water and nutrient use, and controlling weeds, insects or diseases (Willey 1979, Strydhorst et al. 2008). Anil et al. (1998) concluded that in temperate climates intercropping has been more successful when used for forage rather than grain production. More recently, Phelan et al. (2015) stated that the primary agronomic benefits of forage legumes are their contribution to the nitrogen economy of agricultural land due to their association with nitrogen fixing bacteria and their ability to increase herbage production, herbage feed value and ultimately ruminant production of meat and milk, particularly in areas of low fertilizer nitrogen input.

It can be concluded that the nutritive value of different whole crop silages and the effects of replacing grass silage by different whole crop silages on the performance of cattle differs largely depending on the stage of maturity 
A. Huuskonen et al. (2016) 25: 1-12

of the plants at harvest, cutting height, plant species and variety, growing and harvesting conditions as well as harvesting and storage techniques, which all affect the chemical composition, preservation quality and relative proportions of the different crop components, i.e. grain and straw (Wallsten 2008, Rustas 2009, Huuskonen 2013, Keady et al. 2013, Pesonen et al. 2014). In general, the digestibility of whole crop silages is highly dependent on the proportion of straw and is often lower than that of good quality grass silage but the lower digestibility is largely compensated for by higher dry matter intake (DMI) (Sinclair et al. 2003, Huhtanen et al. 2007).

Huuskonen (2013) reported that grass silage could be totally replaced by whole crop barley silage in the diet of dairy bulls when the concentrate constituted 0.4 of diet DM. In a review of seven experiments with finishing beef cattle Keady et al. (2013) concluded that the inclusion of whole crop wheat silage in grass silage based diets increased forage intake by $1.4 \mathrm{~kg} \mathrm{DM} \mathrm{d}^{-1}$, but did not alter animal performance. Huuskonen and Joki-Tokola (2010) concluded that replacing moderately digestible grass silage with whole crop wheat and hairy vetch mixture silage decreased the carcass gain of growing dairy bulls due to lower energy intake and poorer feed conversion. Instead, replacing same moderately digestible grass silage with whole crop barley and hairy vetch mixture silage resulted in similar performance and carcass characteristics (Huuskonen and Joki-Tokola 2010). Recently, Zaralis et al. (2014) reported that whole crop maize silage as forage in diet of finishing bulls can promote high intake and live weight gain. Bulls fed on diets containing maize silage as sole forage achieved higher live weight gain compared to their counterparts fed on diets containing both maize and grass silages (Zaralis et al. 2014).

However, there is paucity of published information on performance, carcass characteristics and meat quality of growing bulls when grass silage is replaced by faba bean or field pea based whole crop legume-cereal silages. Therefore, our objective was to determine the effects of silage plant species (faba bean and field pea based whole crop legume-cereals vs. grass) on animal performance, meat quality and meat fatty acid profile of growing AA and NR bulls. Possible interactions between silage plant species and breed were also examined. It was hypothesized that 1 ) the use of AA bulls improves growth rate, carcass characteristics and meat quality when compared to NR bulls, 2) replacing grass silage by whole crop legume-cereal silages in the diet of growing bulls increases feed intake but does not affect carcass traits and meat quality, and 3) there are no differences in animal performance and meat quality when growing bulls are fed either faba bean-wheat silage or field pea-wheat silage based diets. Furthermore, it was hypothesized that there are no interactions between silage plant species and breed on growth performance, carcass characteristics and meat quality traits. In the present study the target was to feed the bulls according to EU organic farming regulations. Current breeds were chosen because NR is the most frequently used cattle breed in Finland and AA is generally used in organic farming systems.

\section{Materials and methods}

\section{Animals and housing}

A feeding experiment was conducted in the experimental barn of Natural Resources Institute Finland (Luke) in Ruukki, Finland starting in February 2014 and ending in October 2014. Animals were managed according to the Finnish legislation regarding the use of animals in scientific experimentation. The experiment comprised in total $30 \mathrm{AA}$ and $30 \mathrm{NR}$ bulls. All animals, with an initial live weight (LW) of 477 ( \pm 38.7$)(\mathrm{AA})$ and 363 ( \pm 65.9$)(\mathrm{NR}) \mathrm{kg}$, were purchased from commercial herds. At the start of the experiment the animals were on average $341( \pm 13.7)$ (AA) and $304( \pm 35.4)(N R)$ days old.

During the feeding experiment, the bulls were housed in an uninsulated barn in pens $(10.0 \times 5.0 \mathrm{~m}$; 5 bulls in each pen), providing $10.0 \mathrm{~m}^{2}$ per bull. The rear half of the pen area was a straw-bedded lying area and the fore half was a feeding area with a solid concrete floor. A GrowSafe feed intake system (model 4000E; GrowSafe Systems Ltd., Airdrie, AB, Canada; see validation studies: DeVries et al. 2003, Mendes et al. 2011) was used to record individual daily feed intakes so that each pen contained two GrowSafe feeder nodes. The bulls had free access to water from a water bowl (one bowl/pen) during the experiment.

\section{Feeds, feeding and experimental design}

Experimental silages were produced at the experimental farm of Natural Resources Institute Finland in Ruukki $\left(64^{\circ} 44^{\prime} \mathrm{N}, 25^{\circ} 15^{\prime} \mathrm{E}\right)$. All forages were produced in the same field area so the growing conditions were the same. The grass silage (GS) was regrowth from a timothy (Phleum pratense) sward, cut at heading stage of timothy (on 9 August 2013) using a mower without conditioning, wilted for $24 \mathrm{~h}$, and harvested using a precision-chop forage harvester. Two legume-cereal mixtures were field pea (cv. Florida) + wheat (cv. Anniina) (PW) and faba bean 
(cv. Fuego) + wheat (cv. Anniina) (FBW). The sowing rates of the cultivars were $138 \mathrm{~kg}$ pea with $75 \mathrm{~kg}$ wheat and $174 \mathrm{~kg}$ faba bean with $75 \mathrm{~kg}$ wheat ha-1. Both crops were harvested at 12 weeks after sowing (at the early dough stage of wheat) using a direct-cut flail harvester. All silages were treated with a formic acid based additive (AIV ÄSSÄ; Taminco Finland Ltd., Helsinki, Finland; $590 \mathrm{~g}$ formic acid $\mathrm{kg}^{-1}, 200 \mathrm{~g}$ propionic acid $\mathrm{kg}^{-1}, 40 \mathrm{~g}$ ammonium formate $\mathrm{kg}^{-1}$ and $25 \mathrm{~g}$ benzoic acid $\mathrm{kg}^{-1}$ ) applied at a rate of 5 litres $\mathrm{t}^{-1}$ of fresh forage and stored in bunker silos. For botanical determinations ten $25 \mathrm{~cm} \times 50 \mathrm{~cm}$ forage samples were randomly collected from both grass silage and whole crop legume-cereal silage fields before harvesting. On DM basis, GS contained timothy $\left(960 \mathrm{~g} \mathrm{~kg}^{-1}\right)$ and other plants $\left(40 \mathrm{~g} \mathrm{~kg}^{-1}\right)$. Respectively, PW contained pea (891), wheat (107) and other plants (2), and FBW contained faba bean (837), wheat (149) and other plants (14).

A $2 \times 3$ factorial design was used to study the effects of breed and silage plant species on animal performance, carcass characteristics and meat quality. At the beginning of the feeding experiment both AA and NR bulls were randomly allotted to the pens (animals from the same breed were housed together) which were then randomly allotted to three feeding treatments (GSB, FBWB, PWB; two AA pens and two NR pens per diet). The compositions ( $\mathrm{g} \mathrm{kg}^{-1} \mathrm{DM}$ ) of these three diets were: GSB = grass silage (650) and rolled barley (350), FBWB = faba bean-wheat silage (650) and rolled barley (350) and PWB = pea-wheat silage (650) and rolled barley (350). In the present study the concentrate proportion was standardized which is a relatively common method in practical situations on-farm level, and the results are therefore valid from a practical point of view. The experimental diets were offered as total mixed rations ad libitum (proportionate refusals of 5\%). The daily ration for the bulls included also $150 \mathrm{~g}$ of a mineral-vitamin mixture (Kasvuape E-Hiven, A-Rehu Ltd., Seinäjoki, Finland). One AA bull (GSB feeding) was excluded from the study due to hoof problems. There was no reason to suppose that the diet had caused these problems.

\section{Feed sampling and analysis}

During the experiment silage sub-samples were taken twice a week (on Mondays and Thursdays), pooled over periods of four weeks and stored at $-20^{\circ} \mathrm{C}$ prior to analyses. Thawed samples were analysed for DM, ash, crude protein (CP), neutral detergent fibre (NDF), indigestible NDF (iNDF), ether extract, starch, silage fermentation quality $(\mathrm{pH}$, water-soluble carbohydrates [WSC], lactic and formic acids, volatile fatty acids [VFA], soluble and ammonia N content of total N), fatty acids methyl esters and digestible organic matter (DOM) in DM (D-value). Barley sub-samples were collected weekly (on Mondays), pooled over periods of 12 weeks and analysed for DM, ash, $C P, N D F$, iNDF, ether extract and starch.

Fresh silage samples were analysed for fermentation quality by electrometric titration as described by Moisio and Heikonen (1989). The DM concentration was determined by drying at $105{ }^{\circ} \mathrm{C}$ for $20 \mathrm{~h}$ and organic matter (OM) concentration by ashing at $600{ }^{\circ} \mathrm{C}$ for $2 \mathrm{~h}$. Oven DM concentration of silages was corrected for the loss of volatiles according to Huida et al. (1986). After drying the samples were milled using sample mill (Sakomylly KT-3100, Koneteollisuus Oy, Helsinki, Finland) and $1 \mathrm{~mm}$ sieve. The CP content of feeds was determined using a Dumas-type N analyser (Leco FP-428; Leco Corporation, St Joseph, MI, USA). Concentration of NDF was determined using a NDF Method (Method 6): Neutral Detergent Fiber in Feeds - Filter Bag Technique (for A200 and A200I) using 25 microns nylon bags (F57, ANKOM Technology) and ANKOM 220 Fiber Analyzer (ANKOM Technology, 2052 O'Neil Road, Macedon NY 14502). Detergent solution was made according to Van Soest et al. (1991). Sodium sulphite was used in NDF-detergent solution and $\alpha$-amylase in case of samples containing starch. NDF is expressed without containing residual ash. Ether extract was determined according to Huuskonen (2013), iNDF according to Huuskonen et al. (2008) and starch as described by Huuskonen et al. (2014a). The silages were analysed for the fatty acids methyl esters as described by Shingfield et al. (2003) and for D-value as described by Huhtanen et al. (2006). The pepsin-cellulase solubility values were converted to in vivo digestibility using correction equations based on a data set comprising of Finnish in vivo digestibility trials (Huhtanen et al. 2006).

The metabolizable energy (ME) concentration of the silages was calculated as $0.016 \times \mathrm{D}$-value (MAFF 1984). The $\mathrm{ME}$ concentrations of the concentrate feeds were calculated based on concentrations of digestible crude fibre, $\mathrm{CP}$, crude fat and nitrogen-free extract described by MAFF (1984). The digestibility coefficients of the concentrates were taken from the Finnish Feed Tables (Luke 2015). The values of amino acids absorbed from the small intestine (AAT) and the protein balance in the rumen (PBV) were calculated according to the Finnish feed protein evaluation system (Luke 2015) in which PBV describes the balance between the dietary supply of rumen-degradable protein (RDP) and the microbial requirements for RDP. Relative intake potential of silage DM (SDMI index) was calculated as described by Huhtanen et al. (2007). 


\section{Slaughter procedures, carcass and meat quality measurements}

The bulls were weighed on two consecutive days at the beginning of the experiment and before slaughter. The bulls were selected for slaughter based on age, and slaughtered in five batches. The target for average slaughter age was 500 days, and the slaughter age was used as the end point of the study. The LW gain (LWG) was calculated as the difference between the means of the initial and final LW divided by the number of growing days. The estimated rate of carcass gain was calculated as the difference between the final carcass weight and the carcass weight at the beginning of the experiment divided by the number of growing days. The carcass weight at the start of the experiment was assumed to be 0.50 and $0.52 \times$ initial LW for NR and AA bulls, respectively, based on earlier studies (unpublished data).

The animals were slaughtered in the Atria Ltd. commercial slaughterhouse in Kauhajoki, Finland. After slaughter the carcasses were weighed hot. The cold carcass weight was estimated as 0.98 of the hot carcass weight. Dressing proportions were calculated from the ratio of cold carcass weight to final LW. The carcasses were classified for conformation and fatness using the EUROP quality classification (EC 2006). For conformation, the development of the carcass profiles, in particular the essential parts (round, back, shoulder), was taken into consideration according to the EUROP classification (E: excellent, U: very good, R: good, O: fair, P: poor) and for fat cover degree, the amount of fat on the outside of the carcass and in the thoracic cavity was taken into account using a classification range from 1 to 5 (1: low, 2: slight, 3: average, 4: high, 5: very high). Each level of the conformation scale was subdivided into three sub-classes to produce a transformed scale ranging from 1 to 15 , with 15 being the best conformation.

After classification the carcasses were chilled overnight below $7{ }^{\circ} \mathrm{C}$. Day after slaughter the carcasses were commercially cut. Loin ( $M$. longissimus dorsi) was cut at the level of the first lumbar vertebra, and the achieved $3 \mathrm{~kg}$ loin sample between the first and fifth lumbar vertebra was used for further analysis. The marbling score of the loin (at the first lumbar vertebra) was evaluated by using six-point scale ( $0=$ devoid to $5=$ abundant) according to Pesonen et al. (2012). The pH-value of the loin was measured with a Knick 651 instrument with Inlab Solid electrode at the level of the first lumbar vertebra. Meat colour of the loin was measured after a bloom time of half an hour with a Minolta $\mathrm{Cr}-200$ handheld chroma meter (Minolta Camera Co. Ltd., Osaka, Japan). The chroma meter had an $8 \mathrm{~mm}$ diameter measuring area, used diffuse illumination and $0^{\circ}$ viewing angle geometry to provide accurate readings in a wide variety of colour control applications. Before measurements the chroma meter was calibrated to a standard white plate, and CIE Standard Illuminant D65 conditions were used for the measurements. Readings were displayed in $L^{*} a^{*} b^{*}\left(L^{*}\right.$ luminance from 0 to 100 ; $a^{*}$ green to red from -60 to 60 , respectively; and b* blue to yellow from -60 to 60 , respectively). Each sample was measured three times and a mean value was used.

The collected $3 \mathrm{~kg}$ loin sample was vacuum packed for further analysis. Total ageing time of the samples was 12 days at $4{ }^{\circ} \mathrm{C}$, and thereafter samples were analysed for drip loss, Warner-Bratzler shear force, sensory analysis (tenderness, juiciness and beef flavour) and fatty acid composition in intramuscular fat. Drip loss was determined by the amount of water loss from the $3 \mathrm{~kg}$ loin sample after ageing. For shear force measurements, loin samples were heated in a water bath at $85^{\circ} \mathrm{C}$ until the core temperature of the meat was $70{ }^{\circ} \mathrm{C}$. After chilling for 24 hours $\left(4{ }^{\circ} \mathrm{C}\right)$, loin samples were placed in a Warner-Bratzler shear blade to be sheared perpendicular to the longitudinal axis of the muscle fibres in an Instron testing machine and the maximum force was recorded. Each sample was measured 20 times and a mean value was used. For the sensory analysis, surface fat was removed and trimmed loin was cut into four slices with thickness of $1.5 \mathrm{~cm}$. After that these four samples were heated simultaneously up to internal temperature of $68^{\circ} \mathrm{C}$ in a rolling grill (Palux Rotimat, Germany). Heated samples were served immediately in a sensory panel room with white lightning and temperature of $24{ }^{\circ} \mathrm{C}$. Six trained sensory panelists evaluated the samples for tenderness, juiciness and beef flavour. These traits were scored on a seven-point scale (tenderness: 1 = very tough,..., 7 = very tender; juiciness: 1 = very dry,..., 7 = very juicy; beef flavour: $1=$ very non beef like,..., 7 = very beef like). The fatty acid composition in intramuscular fat of the loin was analysed using gas chromatography as described by Pesonen et al. (2013).

\section{Statistical methods}

The results are shown as least squares means. The data were subjected to analysis of variance using the SAS GLM procedure (version 9.3, SAS Institute Inc., Cary, NC, USA). The statistical model used was

$\mathrm{y}_{\mathrm{ijklm}}=\mu+\delta_{\mathrm{k}}+\alpha_{\mathrm{i}}+\gamma_{\mathrm{j}}+(\alpha \times \gamma)_{\mathrm{ij}}+\theta_{\mathrm{ijm}}+\beta \mathrm{x}_{\mathrm{ijkl}}+\mathrm{e}_{\mathrm{ijk} \mathrm{km}}$ 
where $\mu$ is the intercept and $e_{i j k l m}$ is the residual error term associated with $\left.\right|^{\text {th }}$ animal. $\alpha_{i}, \gamma_{j}$ and $(\alpha \times \gamma)_{i j}$ are the effects of $\mathrm{i}^{\text {th }}$ diet (GSB, FBWB, PWB) and $\mathrm{j}^{\text {th }}$ breed (AA, NR) and their interaction, respectively, while $\delta_{k}$ is the effect of the slaughtering batch $(k=1, \ldots, 5)$ and $\theta_{i j m}$ is the effect of pen. The effect of pen was used as an error term when differences between treatments (diet, breed and their interaction) were compared because treatments were allocated to animals penned together. Initial live weight was used as a covariate $\left(\beta x_{i j k l}\right)$ in the model. Differences between the treatments were tested using orthogonal contrasts: (1) AA vs. NR, (2) GSB vs. whole crop legumecereal silage diets (FBWB + PWB), (3) FBWB vs. PWB, (4) interaction between breed and (2), and (5) interaction between breed and (3). Since the interactions between the breed and the feeding treatments were not statistically significant ( $p>0.10$ for all variables), the $p$-values of the interactions are not presented.

\section{Results \\ Feeds and feed intake}

Chemical composition and feeding values of the ingredients and total mixed rations are presented in Table 1. The CP concentration of FBW and PW was 19 and 35\% higher compared to GS, respectively. The grass silage had a higher NDF and lower iNDF and starch concentrations compared to FBW and PW. Further, GS had a $4 \%$ higher $\mathrm{ME}$ content than the whole crop legume-cereal silages. The fermentation characteristics of all three silages were good as indicated by the low $\mathrm{pH}$ value and the low concentrations of ammonia $\mathrm{N}$ in total $\mathrm{N}$ and total fermentation acids. Barley grain used in the experiment had typical chemical composition and feed values.

Table 1. Chemical composition and feeding values (mean \pm standard deviation) of the ingredients and total mixed rations and fatty acid profile (12 most common fatty acids) of the experimental silages used in the feeding experiment. Number of samples: silages 7 , barley grain 3

\begin{tabular}{|c|c|c|c|c|c|c|c|}
\hline & \multicolumn{4}{|c|}{ Feeds } & \multicolumn{3}{|c|}{ Total mixed rations } \\
\hline & GS & FBW & PW & Barley & GSB & FBWB & PWB \\
\hline Dry matter (DM), $\mathrm{g} \mathrm{kg}^{-1}$ & $289 \pm 7.69$ & $277 \pm 19.55$ & $269 \pm 19.18$ & $883 \pm 15.25$ & 378 & 365 & 356 \\
\hline Organic matter (OM), $\mathrm{g} \mathrm{kg}^{-1} \mathrm{DM}$ & $939 \pm 4.33$ & $935 \pm 2.17$ & $930 \pm 6.53$ & $971 \pm 1.98$ & 951 & 948 & 944 \\
\hline Crude protein, $\mathrm{g} \mathrm{kg}^{-1} \mathrm{DM}$ & $129 \pm 3.72$ & $154 \pm 3.77$ & $174 \pm 3.60$ & $107 \pm 3.29$ & 121 & 138 & 151 \\
\hline Neutral detergent fibre (NDF), $\mathrm{g} \mathrm{kg}^{-1} \mathrm{DM}$ & $580 \pm 8.35$ & $465 \pm 15.00$ & $427 \pm 16.70$ & $210 \pm 6.53$ & 451 & 376 & 351 \\
\hline Indigestible NDF, $\mathrm{g} \mathrm{kg}^{-1} \mathrm{DM}$ & $101 \pm 4.82$ & $148 \pm 8.87$ & $148 \pm 14.68$ & $37 \pm 3.81$ & 79 & 109 & 109 \\
\hline Starch, $\mathrm{g} \mathrm{kg}^{-1} \mathrm{DM}$ & $17 \pm 0.08$ & $78 \pm 4.74$ & $56 \pm 3.58$ & $565 \pm 3.76$ & 209 & 248 & 234 \\
\hline Ether extract, $\mathrm{g} \mathrm{kg}^{-1} \mathrm{DM}$ & $42 \pm 3.39$ & $32 \pm 2.27$ & $41 \pm 2.92$ & $22 \pm 0.05$ & 35 & 29 & 34 \\
\hline Metabolizable energy, $\mathrm{MJ} \mathrm{kg}^{-1} \mathrm{DM}$ & $10.1 \pm 0.05$ & $9.7 \pm 0.18$ & $9.7 \pm 0.38$ & $13.2 \pm 0.06$ & 11.2 & 10.9 & 10.9 \\
\hline AAT, $\mathrm{g} \mathrm{kg}^{-1} \mathrm{DM}$ & $75 \pm 0.70$ & $81 \pm 1.07$ & $83 \pm 2.56$ & $95 \pm 1.25$ & 82 & 86 & 87 \\
\hline Protein balance in the rumen, $\mathrm{g} \mathrm{kg}^{-1} \mathrm{DM}$ & $17 \pm 2.19$ & $36 \pm 4.65$ & $53 \pm 5.88$ & $-36 \pm 6.73$ & -2 & 11 & 22 \\
\hline Digestible OM in DM, $\mathrm{g} \mathrm{kg}^{-1} \mathrm{DM}$ & $629 \pm 5.86$ & $608 \pm 12.74$ & $608 \pm 17.23$ & $821 \pm 4.56$ & 696 & 683 & 683 \\
\hline Silage DM intake index & $93 \pm 3.33$ & $109 \pm 3.45$ & $104 \pm 4.49$ & & & & \\
\hline \multicolumn{8}{|l|}{ Fermentation quality of silages } \\
\hline $\mathrm{pH}$ & $3.96 \pm 0.07$ & $3.79 \pm 0.11$ & $3.98 \pm 0.15$ & & & & \\
\hline Volatile fatty acids, $\mathrm{g} \mathrm{kg}^{-1} \mathrm{DM}$ & $14 \pm 4.04$ & $13 \pm 2.99$ & $16 \pm 2.07$ & & & & \\
\hline Lactic + formic acid, $\mathrm{g} \mathrm{kg}^{-1} \mathrm{DM}$ & $45 \pm 6.39$ & $71 \pm 15.69$ & $57 \pm 12.91$ & & & & \\
\hline $\begin{array}{l}\text { Water soluble carbohydrates, } \mathrm{g} \mathrm{kg}^{-1} \mathrm{DM} \\
\text { In total } \mathrm{N}, \mathrm{g} \mathrm{kg}^{-1}\end{array}$ & $59 \pm 13.66$ & $30 \pm 8.62$ & $28 \pm 10.86$ & & & & \\
\hline $\mathrm{NH}_{4} \mathrm{~N}$ & $43 \pm 6.91$ & $49 \pm 9.73$ & $66 \pm 7.73$ & & & & \\
\hline Soluble N & $410 \pm 22.19$ & $398 \pm 64.54$ & $500 \pm 68.50$ & & & & \\
\hline \multicolumn{8}{|l|}{ Fatty acids, g/100 g of fatty acids } \\
\hline $16: 0$ & $17.65 \pm 2.07$ & $16.22 \pm 0.83$ & $20.83 \pm 1.06$ & & & & \\
\hline $16: 1 n-7$ & $2.57 \pm 0.73$ & $4.82 \pm 0.41$ & $4.63 \pm 0.36$ & & & & \\
\hline 18:0 & $1.70 \pm 0.34$ & $2.12 \pm 0.21$ & $2.99 \pm 0.10$ & & & & \\
\hline $18: 1 \mathrm{n}-9$ & $3.10 \pm 1.12$ & $2.55 \pm 0.30$ & $4.04 \pm 0.20$ & & & & \\
\hline $18: 2 n-6$ & $18.00 \pm 0.86$ & $27.63 \pm 0.75$ & $23.11 \pm 0.19$ & & & & \\
\hline $18: 3 n-3$ & $42.06 \pm 5.39$ & $39.19 \pm 1.02$ & $34.62 \pm 0.94$ & & & & \\
\hline $20: 0$ & $1.39 \pm 0.27$ & $1.12 \pm 0.16$ & $1.33 \pm 0.43$ & & & & \\
\hline 22:0 & $2.06 \pm 0.37$ & $0.85 \pm 0.08$ & $0.81 \pm 0.09$ & & & & \\
\hline 24:0 & $1.34 \pm 0.29$ & $0.94 \pm 0.06$ & $0.96 \pm 0.03$ & & & & \\
\hline 26:0 & $2.00 \pm 0.43$ & $0.29 \pm 0.03$ & $0.47 \pm 0.04$ & & & & \\
\hline 28:0 & $2.09 \pm 0.66$ & $0.14 \pm 0.04$ & $0.30 \pm 0.02$ & & & & \\
\hline $30: 0$ & $1.05 \pm 0.31$ & $0.17 \pm 0.03$ & $0.22 \pm 0.01$ & & & & \\
\hline Saturated fatty acids & $31.38 \pm 4.52$ & $23.89 \pm 1.30$ & $31.02 \pm 1.18$ & & & & \\
\hline Monounsaturated fatty acids & $8.00 \pm 1.37$ & $8.61 \pm 0.43$ & $10.70 \pm 0.29$ & & & & \\
\hline Polyunsaturated fatty acids & $60.62 \pm 5.83$ & $67.50 \pm 1.73$ & $58.28 \pm 1.07$ & & & & \\
\hline
\end{tabular}


A. Huuskonen et al. (2016) 25: 1-12

Due to differences in composition of the experimental silages, FBWB and PWB rations included 14 and $25 \%$ more $\mathrm{CP}$ and 19 and $12 \%$ more starch compared to GSB, respectively. Further, FBWB and PWB rations included less NDF and more iNDF compared to GSB. In all rations the PBV value fulfilled the Finnish recommendation for growing cattle (PBV of the diet above $-10 \mathrm{~g} \mathrm{~kg}^{-1} \mathrm{DMI}$ for animals above $200 \mathrm{~kg} \mathrm{LW}$ ). There were no considerable differences in $\mathrm{ME}$ contents among the experimental diets (difference less than $3 \%$ ).

Although, all silages exhibited quite similar fatty acid profiles, GS contained a higher proportion of $\alpha$-linolenic acid $(18: 3 \mathrm{n} 3)$ and a lower proportion of linoleic acid (18:2 n6) than FBW and PW (Table 1). The dominant saturated fatty acid (SFA) in GS, FBW and PW was palmitic acid (16:0) at 17.7, 16.2 and $20.8 \%$ of total fatty acids, respectively. The dominant unsaturated fatty acid was $\alpha$-linolenic acid, at $42.1,39.2$ and $34.6 \%$ of total fatty acids in GS, FBW and PW, respectively.

The slaughter age was on average 498 and 509 days for AA and NR bulls, respectively, and there were no treatment differences in the slaughter age (Table 2). The final LW of the AA bulls (709 kg, on average) was $18 \%$ higher $(p<0.001)$ compared to the NR bulls $(600 \mathrm{~kg})$. In addition, the final LW of the FBWB bulls tended to be $(p=0.09)$ higher than that of the PWB bulls. During the experiment the total DMI of the AA bulls was $12 \%$ higher $(p<0.01)$ compared to the NR bulls. However, DMI in relation to LW was $11 \%(p=0.01)$ and DMI per metabolic LW tended to be $5 \%(p=0.10)$ higher in the NR bulls compared to the AA bulls. Due to higher total DMI, daily ME, CP, NDF and starch intakes of the AA bulls were higher $(p<0.01)$ compared to the NR bulls. However, ME and CP intakes in relation to LW were 12 and $11 \%$ higher $(p<0.05)$ in the NR bulls compared to the AA bulls, respectively.

Table 2. Intake and growth performance of the bulls fed different total mixed rations

\begin{tabular}{|c|c|c|c|c|c|c|c|c|c|c|}
\hline \multirow{2}{*}{$\begin{array}{l}\text { Breed } \\
\text { Feeding }\end{array}$} & \multicolumn{3}{|c|}{ Aberdeen Angus } & \multicolumn{3}{|c|}{ Nordic Red } & \multirow{2}{*}{ SEM } & \multicolumn{3}{|c|}{$\begin{array}{l}\text { Orthogonal contrasts } \\
\text { ( } p \text {-values) }\end{array}$} \\
\hline & GSB & FBWB & PWB & GSB & FBWB & PWB & & 1 & 2 & 3 \\
\hline Number of observations & 9 & 10 & 10 & 10 & 10 & 10 & & & & \\
\hline Duration of the experiment, $d$ & 155 & 165 & 150 & 203 & 215 & 194 & 5.7 & $<0.001$ & 0.75 & 0.02 \\
\hline Initial live weight (LW), kg & 481 & 473 & 478 & 373 & 366 & 349 & 11.7 & $<0.001$ & 0.34 & 0.63 \\
\hline Final LW, kg & 708 & 713 & 707 & 609 & 622 & 570 & 14.7 & $<0.001$ & 0.67 & 0.09 \\
\hline Slaughter age, d & 496 & 503 & 495 & 504 & 522 & 500 & 8.2 & 0.17 & 0.56 & 0.12 \\
\hline \multicolumn{11}{|l|}{ Intake } \\
\hline Silage, kg dry matter (DM) $d^{-1}$ & 7.84 & 8.70 & 7.90 & 7.02 & 8.01 & 6.79 & - & - & - & - \\
\hline Concentrate, kg DM d ${ }^{-1}$ & 4.36 & 4.70 & 4.25 & 3.93 & 4.32 & 3.65 & - & - & - & - \\
\hline Total DM intake, $\mathrm{kg} \mathrm{d}^{-1}$ & 12.20 & 13.40 & 12.15 & 10.95 & 12.33 & 10.44 & 0.380 & 0.005 & 0.18 & 0.006 \\
\hline DM intake, $\mathrm{g} \mathrm{kg}^{-1} \mathrm{LW}$ & 20.5 & 22.6 & 20.5 & 22.6 & 25.2 & 23.1 & 0.82 & 0.01 & 0.12 & 0.04 \\
\hline $\begin{array}{l}\text { DM intake, } \mathrm{g} \mathrm{kg}^{-1} \text { metabolic } \\
\mathrm{LW}\left(\mathrm{LW}^{0.75}\right)\end{array}$ & 101 & 112 & 101 & 106 & 119 & 106 & 3.5 & 0.10 & 0.11 & 0.02 \\
\hline $\begin{array}{l}\text { Metabolizable energy (ME), } \\
\mathrm{MJ} \mathrm{d}^{-1}\end{array}$ & 136 & 143 & 132 & 123 & 132 & 113 & 4.1 & 0.005 & 0.85 & 0.01 \\
\hline ME intake, $\mathrm{MJ} \mathrm{kg}{ }^{-1} \mathrm{LW}$ & 0.23 & 0.24 & 0.22 & 0.25 & 0.27 & 0.25 & 0.009 & 0.01 & 0.52 & 0.07 \\
\hline $\begin{array}{l}\text { ME intake, MJ kg-1 metabolic } \\
\text { LW }\end{array}$ & 1.13 & 1.19 & 1.10 & 1.19 & 1.27 & 1.15 & 0.038 & 0.10 & 0.57 & 0.04 \\
\hline Crude protein $(C P), \mathrm{g} \mathrm{d}^{-1}$ & 1457 & 1840 & 1834 & 1317 & 1688 & 1565 & 51.0 & 0.004 & $<0.001$ & 0.25 \\
\hline $\mathrm{CP}, \mathrm{g} \mathrm{kg}^{-1} \mathrm{LW}$ & 2.45 & 3.11 & 3.10 & 2.72 & 3.46 & 3.46 & 0.118 & 0.02 & $<0.001$ & 0.98 \\
\hline $\mathrm{CP}, \mathrm{g} \mathrm{kg}^{-1}$ metabolic LW & 12.1 & 15.3 & 15.3 & 12.7 & 16.2 & 15.9 & 0.502 & 0.13 & $<0.001$ & 0.74 \\
\hline Neutral detergent fibre, $\mathrm{g} \mathrm{d}^{-1}$ & 5443 & 5046 & 4136 & 4858 & 4621 & 3585 & 143.7 & 0.004 & $<0.001$ & $<0.001$ \\
\hline Starch, $\mathrm{g} \mathrm{d}^{-1}$ & 2592 & 3332 & 2844 & 2345 & 3065 & 2445 & 108.5 & 0.007 & $<0.001$ & $<0.001$ \\
\hline Live weight gain, $\mathrm{g} \mathrm{d}^{-1}$ & 1479 & 1496 & 1569 & 1162 & 1197 & 1140 & 40.3 & $<0.001$ & 0.42 & 0.84 \\
\hline Carcass gain, $\mathrm{g} \mathrm{d}^{-1}$ & 866 & 837 & 868 & 589 & 633 & 599 & 21.3 & $<0.001$ & 0.74 & 0.95 \\
\hline \multicolumn{11}{|l|}{ Feed conversion } \\
\hline Kg DM/kg carcass gain & 14.2 & 16.1 & 14.1 & 18.9 & 19.8 & 17.9 & 0.29 & $<0.001$ & 0.13 & $<0.001$ \\
\hline MJ ME/kg carcass gain & 159 & 172 & 154 & 211 & 212 & 194 & 3.1 & $<0.001$ & 0.47 & 0.001 \\
\hline g CP/kg carcass gain & 1688 & 2223 & 2154 & 2236 & 2714 & 2641 & 36.8 & $<0.001$ & $<0.001$ & 0.19 \\
\hline
\end{tabular}

GSB = grass silage $(650 \mathrm{~g} / \mathrm{kg} \mathrm{DM})$ + rolled barley (350); FBWB = faba bean-wheat silage $(650)$ + rolled barley (350); PWB = pea-wheat silage (650) + rolled barley (350)

Orthogonal contrasts: 1 = Aberdeen Angus vs. Nordic Red, 2 = GS vs. whole crop legume-cereal silages (FBW + PW), 3 = FBW vs. PW

$\mathrm{SEM}=$ standard error of mean 
A. Huuskonen et al. (2016) 25: 1-12

Feeding treatments affected intake parameters (Table 2). The total DM and energy intakes were significantly higher in the FBWB bulls compared to the PWB bulls. Furthermore, DM and ME intakes in relation to LW and metabolic LW were higher in the FBWB bulls compared to the PWB bulls. Crude protein, NDF and starch intakes were higher $(p<0.001)$ with whole crop legume silage based diets compared to GSB. In addition, FBWB diet increased NDF and starch intake compared to PWB diet $(p<0.001)$.

\section{Growth performance, feed conversion and carcass characteristics}

Live weight gain and carcass gain of the AA bulls were 30 and $41 \%$ higher $(p<0.001)$, respectively, compared to the NR bulls but there were no differences among feeding treatments in growth performance (Table 2). Dry matter, energy and CP conversion rates of the AA bulls were better $(p<0.001)$ compared to the NR bulls. There were no significant differences in DM or energy conversion rates when whole crop legume silage based diets were compared to GSB. However, CP conversion was better $(p<0.001)$ with GSB compared to whole crop legume silage based diets. Further, DM and energy conversion rates were better in PWB bulls than in FBWB bulls (Table 2).

The carcass weight, dressing proportion, carcass conformation score and carcass fat score of the AA bulls were clearly higher $(p<0.001)$ than the corresponding values of the NR bulls (Table 3 ). There were no significant differences in above mentioned carcass traits between whole crop legume silage and GSB based diets. However, the carcass weight of the FBWB bulls was $9 \%(p=0.02)$, carcass conformation score $8 \%(p=0.04)$ and carcass fat score $10 \%(p=0.09)$ higher, on average, compared to the PWB bulls.

Table 3. Carcass traits and meat quality (M. longissimus dorsi) of the bulls fed different total mixed rations

\begin{tabular}{|c|c|c|c|c|c|c|c|c|c|c|}
\hline \multirow{2}{*}{$\begin{array}{l}\text { Breed } \\
\text { Feeding }\end{array}$} & \multicolumn{3}{|c|}{ Aberdeen Angus } & \multicolumn{3}{|c|}{ Nordic Red } & \multirow{2}{*}{ SEM } & \multicolumn{3}{|c|}{$\begin{array}{c}\text { Orthogonal contrasts } \\
\text { ( } p \text {-values })\end{array}$} \\
\hline & GSB & FBWB & PWB & GSB & FBWB & PWB & & 1 & 2 & 3 \\
\hline Number of observations & 9 & 10 & 10 & 10 & 10 & 10 & & & & \\
\hline \multicolumn{11}{|l|}{ Carcass characteristics } \\
\hline Carcass weight, kg & 379 & 376 & 372 & 302 & 314 & 287 & 7.6 & $<0.001$ & 0.62 & 0.02 \\
\hline Dressing proportion, $\mathrm{g} \mathrm{kg}^{-1}$ & 535 & 528 & 526 & 496 & 506 & 502 & 2.7 & $<0.001$ & 0.94 & 0.30 \\
\hline Conformation, EUROP & 8.4 & 8.5 & 7.7 & 4.9 & 5.1 & 4.9 & 0.20 & $<0.001$ & 0.67 & 0.04 \\
\hline Fat score, EUROP & 3.1 & 3.2 & 3.3 & 2.3 & 2.5 & 1.9 & 0.13 & $<0.001$ & 0.91 & 0.09 \\
\hline \multicolumn{11}{|c|}{ Quality of longissimus dorsi muscle } \\
\hline $\mathrm{pH}$ (24 h post mortem) & 5.57 & 5.53 & 5.52 & 5.66 & 5.58 & 5.61 & 0.026 & 0.008 & 0.009 & 0.91 \\
\hline $\begin{array}{l}\text { Marbling score }(0=\text { devoid, } 5= \\
\text { abundant) }\end{array}$ & 1.56 & 2.31 & 1.97 & 1.06 & 1.56 & 1.22 & 0.295 & 0.004 & 0.08 & 0.71 \\
\hline Drip loss, \% & 0.22 & 0.22 & 0.19 & 0.27 & 0.33 & 0.36 & 0.031 & 0.01 & 0.32 & 0.98 \\
\hline Shear force, $\mathrm{N}$ & 48.8 & 49.6 & 48.1 & 58.8 & 54.6 & 63.0 & 4.11 & 0.007 & 0.98 & 0.82 \\
\hline \multicolumn{11}{|l|}{ Colour } \\
\hline L (lightness) & 36.2 & 36.9 & 36.8 & 34.4 & 34.6 & 33.9 & 0.77 & $<0.001$ & 0.71 & 0.97 \\
\hline a (redness) & 22.6 & 23.0 & 22.7 & 21.1 & 23.0 & 21.3 & 0.81 & 0.02 & 0.32 & 0.51 \\
\hline b (yellowness) & 7.5 & 8.0 & 7.1 & 6.5 & 6.9 & 6.3 & 0.43 & 0.003 & 0.77 & 0.15 \\
\hline \multicolumn{11}{|l|}{ Sensory analysis } \\
\hline Tenderness & 5.8 & 5.7 & 5.9 & 5.1 & 5.2 & 5.0 & 0.27 & 0.009 & 0.95 & 0.56 \\
\hline Juiciness & 5.7 & 5.7 & 5.8 & 5.4 & 5.5 & 5.4 & 0.15 & 0.02 & 0.82 & 0.59 \\
\hline Beef flavour & 5.9 & 5.8 & 5.7 & 5.6 & 5.7 & 5.5 & 0.13 & 0.19 & 0.41 & 0.86 \\
\hline $\begin{array}{l}\text { GSB = grass silage }(650 \mathrm{~g} / \mathrm{kg} \mathrm{DM})+ \\
(650)+\text { rolled barley }(350) \\
\text { Orthogonal contrasts: } 1 \text { = Aberdeer } \\
\text { Sensory analysis: scale from } 1 \text { to } 7 \text {, } \\
\text { non beef like, } 7 \text { = very beef like } \\
\text { SEM = standard error of mean }\end{array}$ & ness: 1 & $\begin{array}{l}\text { dic Red, } \\
=\text { very to }\end{array}$ & $\begin{array}{l}=\mathrm{GS} v \\
\mathrm{gh}, 7=\end{array}$ & $y$ tend & $\begin{array}{l}\text { p legum } \\
\text { juicines }\end{array}$ & $\begin{array}{l}\text {-cereal } \\
: 1=\mathrm{ve}\end{array}$ & $y, 7=v \epsilon$ & $\begin{array}{l}\text { W), } 3=\text { F } \\
\text { uicy, beef }\end{array}$ & $\begin{array}{l}N \text { vs. PV } \\
\text { avour: } 1\end{array}$ & $\begin{array}{l}\text { silage } \\
\text { very }\end{array}$ \\
\hline
\end{tabular}




\section{Meat quality}

Feeding treatments had only minor effects on meat quality parameters (Table 3). The $\mathrm{pH}$-value of the loin was slightly lower with whole crop legume silage based diets compared to GSB $(p<0.01)$. In addition, whole crop legume silage based diets tended to increase marbling score compared to GSB $(p=0.08)$. However, feeding did not affect drip loss, colour, shear force or sensory analysis. On the contrary, breed had clear effects on meat quality (Table 3). The loin of the AA bulls had lower $\mathrm{pH}$, drip loss and shear force values and higher marbling score compared to the NR bulls $(p<0.01)$. Further, muscle lightness, redness and yellowness values of the AA bulls were higher than those of the NR bulls. In the sensory analyses, the AA bulls got higher scores in tenderness $(p<0.01)$ and juiciness $(p=0.02)$ compared to the NR bulls.

The loin samples of the AA-bulls contained a higher $(p=0.01)$ proportion of SFA and tended to contain lower $(p=0.06)$ proportion of monounsaturated fatty acids (MUFA) compared to the NR bulls (Table 4). The n6/n3 fatty acid ratio of the NR-bulls was $40 \%$ higher $(p<0.001)$ than the corresponding value of the AA-bulls, on average. In the case of single fatty acids, the loin of the AA bulls had a higher proportion of 15:0 $(p<0.001), 15: 1$ $(p<0.001), 16: 0(p<0.001)$, trans-9 16:1 ( $p<0.05), 17: 0(p<0.001)$, iso17:0 $(p<0.01)$ and cis-9, trans-11 18:2 CLA $(p=0.01)$ fatty acids compared to that of the NR bulls. On the contrary, the loin of the NR bulls contained a higher proportion of 14:1n5 ( $p<0.001), 16: 1 n 7(p<0.01), 17: 1 n 7(p<0.05), 18: 2 n 6(p<0.001), 20: 1 n 9(p<0.01), 20: 3 n 6$ $(p<0.01)$ and $20: 4 n 6(p<0.01)$ fatty acids compared to that of the AA bulls.

Table 4. Fatty acid profile (\% of total fatty acids) of longissimus dorsi muscle of the bulls fed different total mixed rations

\begin{tabular}{|c|c|c|c|c|c|c|c|c|c|c|}
\hline \multirow{2}{*}{$\begin{array}{l}\text { Breed } \\
\text { Feeding }\end{array}$} & \multicolumn{3}{|c|}{ Aberdeen Angus } & \multicolumn{3}{|c|}{ Nordic Red } & \multirow{2}{*}{ SEM } & \multicolumn{3}{|c|}{$\begin{array}{l}\text { Orthogonal contrasts } \\
\text { ( } p \text {-values) }\end{array}$} \\
\hline & GSB & FBWB & PWB & GSB & FBWB & PWB & & 1 & 2 & 3 \\
\hline Number of observations & 9 & 10 & 10 & 10 & 10 & 10 & & & & \\
\hline $14: 0$ & 2.24 & 2.30 & 2.42 & 2.16 & 2.44 & 2.25 & 0.140 & 0.08 & 0.22 & 0.69 \\
\hline $14: 1 n-5$ & 1.13 & 1.10 & 1.26 & 1.39 & 1.31 & 1.28 & 0.105 & 0.001 & 0.85 & 0.92 \\
\hline $15: 0$ & 0.43 & 0.42 & 0.45 & 0.34 & 0.37 & 0.43 & 0.025 & $<0.001$ & 0.15 & 0.03 \\
\hline $15: 1$ & 0.25 & 0.25 & 0.24 & 0.21 & 0.21 & 0.20 & 0.017 & $<0.001$ & 0.60 & 0.73 \\
\hline $16: 0$ & 25.72 & 26.22 & 26.40 & 24.32 & 25.53 & 24.94 & 0.538 & $<0.001$ & 0.11 & 0.92 \\
\hline $16: 1 n-7$ & 3.33 & 3.41 & 3.50 & 3.92 & 4.25 & 3.53 & 0.161 & 0.01 & 0.70 & 0.15 \\
\hline trans-9 16:1 & 0.48 & 0.39 & 0.38 & 0.42 & 0.35 & 0.35 & 0.017 & 0.04 & $<0.001$ & 0.40 \\
\hline $17: 0$ & 1.08 & 1.13 & 1.24 & 0.92 & 0.98 & 1.12 & 0.044 & $<0.001$ & 0.002 & 0.92 \\
\hline iso $17: 0$ & 0.21 & 0.20 & 0.19 & 0.17 & 0.16 & 0.17 & 0.009 & 0.008 & 0.11 & 0.90 \\
\hline $17: 1 \mathrm{n}-7$ & 1.56 & 1.28 & 1.48 & 1.62 & 1.41 & 1.44 & 0.111 & 0.03 & 0.04 & 0.73 \\
\hline $18: 0$ & 15.79 & 15.34 & 15.00 & 14.14 & 13.87 & 15.98 & 0.600 & 0.13 & 0.92 & 0.07 \\
\hline iso $18: 0$ & 0.21 & 0.19 & 0.19 & 0.15 & 0.16 & 0.21 & 0.032 & 0.87 & 0.70 & 0.35 \\
\hline $18: 1 n-9$ & 37.91 & 38.89 & 38.01 & 39.89 & 39.22 & 37.59 & 0.877 & 0.11 & 0.55 & 0.08 \\
\hline trans-11 18:1 & 1.26 & 1.27 & 1.22 & 1.12 & 1.21 & 1.25 & 0.069 & 0.86 & 0.39 & 0.70 \\
\hline $18: 2 n-6$ & 3.19 & 3.06 & 3.12 & 3.71 & 3.59 & 4.11 & 0.262 & $<0.001$ & 0.81 & 0.52 \\
\hline cis-9,trans-11 18:2 CLA & 0.64 & 0.64 & 0.61 & 0.54 & 0.52 & 0.46 & 0.041 & 0.01 & 0.37 & 0.15 \\
\hline $18: 3 n-3$ & 0.74 & 0.76 & 0.73 & 0.68 & 0.73 & 0.76 & 0.051 & 0.69 & 0.37 & 0.93 \\
\hline $20: 0$ & 0.21 & 0.18 & 0.18 & 0.20 & 0.18 & 0.21 & 0.022 & 0.29 & 0.45 & 0.19 \\
\hline $20: 1 n-9$ & 0.34 & 0.31 & 0.32 & 0.40 & 0.38 & 0.39 & 0.020 & 0.002 & 0.21 & 0.76 \\
\hline $20: 2 n-6$ & 0.24 & 0.19 & 0.19 & 0.27 & 0.23 & 0.22 & 0.024 & 0.18 & 0.02 & 0.70 \\
\hline $20: 3 n-6$ & 0.20 & 0.18 & 0.20 & 0.28 & 0.24 & 0.25 & 0.031 & 0.002 & 0.44 & 0.99 \\
\hline $20: 4 n-6$ & 0.62 & 0.51 & 0.62 & 0.89 & 0.66 & 0.81 & 0.128 & 0.002 & 0.39 & 0.78 \\
\hline $20: 5 n-3$ & 0.27 & 0.17 & 0.24 & 0.16 & 0.14 & 0.16 & 0.044 & 0.87 & 0.34 & 0.66 \\
\hline $22: 0$ & 0.08 & 0.05 & 0.06 & 0.06 & 0.05 & 0.05 & 0.009 & 0.54 & 0.02 & 0.45 \\
\hline $22: 1$ n-9 & 0.03 & 0.02 & 0.03 & 0.04 & 0.03 & 0.03 & 0.006 & 0.88 & 0.14 & 0.92 \\
\hline $22: 2 n-6$ & 0.07 & 0.08 & 0.06 & 0.09 & 0.09 & 0.08 & 0.017 & 0.39 & 0.99 & 0.41 \\
\hline $22: 4 n-6$ & 0.10 & 0.08 & 0.08 & 0.11 & 0.10 & 0.10 & 0.016 & 0.11 & 0.39 & 0.80 \\
\hline $22: 5 n-3$ & 0.35 & 0.26 & 0.34 & 0.30 & 0.25 & 0.28 & 0.056 & 0.39 & 0.45 & 0.63 \\
\hline $22: 6 n-6$ & 0.06 & 0.02 & 0.05 & 0.04 & 0.03 & 0.04 & 0.010 & 0.39 & 0.12 & 0.20 \\
\hline Saturated fatty acids & 45.92 & 46.00 & 46.10 & 42.44 & 43.71 & 45.33 & 0.918 & $<0.001$ & 0.18 & 0.11 \\
\hline $\begin{array}{l}\text { Monounsaturated fatty } \\
\text { acids }\end{array}$ & 46.27 & 46.90 & 46.40 & 48.99 & 48.36 & 46.02 & 0.923 & 0.01 & 0.38 & 0.05 \\
\hline $\begin{array}{l}\text { Polyunsaturated fatty } \\
\text { acids }\end{array}$ & 6.71 & 6.24 & 6.57 & 7.53 & 7.00 & 7.71 & 0.574 & 0.006 & 0.71 & 0.72 \\
\hline$n 6 / n 3$ fatty acid ratio & 3.01 & 3.19 & 3.09 & 4.32 & 4.26 & 4.47 & 0.134 & $<0.001$ & 0.34 & 0.91 \\
\hline
\end{tabular}

GSB = grass silage $(650 \mathrm{~g} / \mathrm{kg} \mathrm{DM})+$ rolled barley $(350), \mathrm{FBWB}=$ faba bean-wheat silage $(650)+$ rolled barley $(350), \mathrm{PWB}=$ pea-wheat silage $(650)+$ rolled barley $(350)$

Orthogonal contrasts: 1 = Aberdeen Angus vs. Nordic Red, 2 = GS vs. whole crop legume-cereal silages (FBW + PW), $3=\mathrm{FBW}$ vs. PW $\mathrm{SEM}=$ standard error of mean 
A. Huuskonen et al. (2016) 25: 1-12

FBWB diet increased $(p=0.05)$ the MUFA proportion compared to PWB diet but feeding treatments did not affect the proportions of SFA or polyunsaturated fatty acids (PUFA). Moreover, feeding treatments had no effect on the $\mathrm{n} 6 / \mathrm{n} 3$ fatty acid ratio. Whole crop legume silage based diets increased the proportion of 17:0 $(p<0.01)$ fatty acid and decreased the proportions of trans-9 16:1 $(p<0.001), 20: 2 n 6(p<0.05)$ and 22:0 $(p<0.05)$ fatty acids compared to the GSB diet. The PWB diet increased $(p<0.05)$ the proportion of 15:0 fatty acid compared to the FBWB diet (Table 4).

\section{Discussion}

\section{Feed intake}

In the present study the total DMI in relation to LW was higher in the NR bulls compared to the AA bulls, which is in agreement with previously reported findings. For example, Cummins et al. (2007) reported that Friesian steers had higher silage DMI than beef-cross animals and, as a consequence, had higher total DM and net energy intakes over the entire finishing period. The higher silage and total DMI of the pure dairy animals was also observed by Keane and Allen (2002) for comparisons of Friesian-Holstein with Friesian-Holstein $\times$ Piedmontese and FriesianHolstein $\times$ Romagnola steers. These results from the literature demonstrate that growing dairy breed cattle have a higher intake than beef breeds when the diet is forage-based, as in the present study. However, due to higher LW and total daily DMI, daily nutrient intakes of the AA bulls were higher compared to the NR bulls in the present experiment.

The reason for the higher total DMI in the FBWB diet compared to the PWB diet is partly unclear because there were no remarkable differences between FBW and PW silages in chemical composition or fermentation quality even if FBW had slightly higher SDMI index compared to PW. In a recent meta-analysis Huuskonen et al. (2013a) reported that feed intake of growing cattle can be predicted from LW and diet composition with a reasonable accuracy. Expectedly, LW was the most important variable predicting total DMI. The intake model was improved when adjusted for dietary variables (dietary NDF concentration, SDMI index and dietary concentration of VFA). The following non-linear equation for the relationship between total DMI, LW and dietary variables was defined: DMI $\left(\mathrm{kg} \mathrm{d}^{-1}\right)=(0.199-0.380 \times \mathrm{NDF}+0.000348 \times$ SDMI-index $-0.00044 \times$ VFA $) \times$ LW $^{(0.624+0.348 \times \text { NDF) }}$ (Huuskonen et al. 2013a). Based on the above equation and the dietary compositions of the present rations, the predicted difference in total DMI between FBWB and PWB bulls would be only $2 \%$. However, in the present experiment the measured difference was approximately $10 \%$.

In general, the DMI of silage can be affected by its DM content, fermentation characteristics, NDF concentration, organic matter digestibility and type of feed (Huhtanen et al. 2007). Both finishing beef cattle (Keady et al. 2013) and dairy cows (Ahvenjärvi et al. 2006) have been able to maintain or even increase silage DMI after inclusion of whole crop silage into the diet, although the digestibility of whole crop silage has been lower than that of the grass silage. One factor contributing to this effect could be the lower NDF concentration in whole-crop silages. According to Huhtanen et al. (2007), the responses to replacing grass silages partially or totally with legume or whole crop silages on silage DMI in dairy cows could not be accurately predicted from differences in silage D-value, DM concentration or fermentation characteristics. Huhtanen et al. (2007) observed that when the cows were fed mixtures of grass and legume or whole crop silages, the silage DMI was generally higher than predicted from silage characteristics.

\section{Growth performance, feed conversion and carcass characteristics}

The AA bulls grew faster, had better feed conversion rates and superior dressing proportion and carcass conformation compared to the NR bulls in line with numerous earlier studies comparing beef and dairy breeds (e.g. More O'Ferrall and Keane 1990, Pfuhl et al. 2007, Alberti et al. 2008). Also datasets collected from slaughterhouses show superior growth and carcass conformation of beef breeds compared to dairy breeds in Finnish cattle population (Huuskonen et al. 2013b, Huuskonen 2014, Pesonen and Huuskonen 2015). The lower dressing proportion and conformation score of the NR bulls in the present experiment can also be explained partly by their lower average carcass weight compared to AA bulls because it is well established that these traits increased with increasing carcass weight (e.g. Kempster et al. 1988).

The dietary treatments did not affect LWG or carcass gain but the carcass weight of the FBWB bulls was higher compared to the PWB bulls. It was probably due to differences in carcass weight that the carcasses in the FBWB diet were better conformed and had more subcutaneous fat than the carcasses in the PWB diet. 
A. Huuskonen et al. (2016) 25: 1-12

In general, carcass conformation and fat score increase with higher carcass weight (Kempster et al. 1988, Keane and Allen 1998). The poorer DM and energy conversion rates of the FBWB bulls compared to the PWB bulls was due to their higher DMI but similar growth rate. Protein conversion rate was clearly better with GSB compared to the whole crop legume silage based diets because also in the GSB ration the PBV value fulfilled the protein recommendation for growing cattle. Therefore, the bulls could not utilize the additional protein obtained through feeding the whole crop legume silages. A recent meta-analysis (Huuskonen et al. 2014b) and feeding experiments (Huuskonen 2013, Pesonen et al. 2014) indicate that currently recommended PBV (PBV of the diet above $-10 \mathrm{~g}$ $\mathrm{kg}^{-1}$ DMI for animals above $200 \mathrm{~kg}$ LW, Luke 2015) could even be reduced without adverse effects on growth performance and carcass traits. When a large part of the extra dietary protein would be excreted in urine (Huuskonen et al. 2014b), the increased forage protein content compared to grass silages or pure whole crop silages is not a sufficient justification for using forage legumes in the diet of growing cattle.

\section{Meat quality}

The slaughter age was used as the end point of the study in the present experiment. Therefore, there were great differences between breeds in carcass weight and carcass fatness which can partly explain the differences in meat quality traits. It is often assumed that the traditional beef breeds, such as AA, have better flavour than dairy breeds, although there is little scientific evidence for this. For example, Elmore et al. (2004) reported that only slight effects of breed were observed in a comparison of the aroma volatiles and fatty acid compositions of grilled beef muscle from AA and Holstein-Friesian steers. Pfuhl et al. (2007) concluded that Holstein bulls showed a greater marbling score, darker colour, and more water binding capacity compared to Charolais bulls.

The present results suggest that AA bulls produced healthier meat with a lower $n 6 / n 3$ fatty acid ratio and higher cis-9, trans-11 18:2 CLA concentration compared to NR bulls. Breed differences and associated effects of maturity or growth potential on the subcutaneous or intramuscular fatty acid composition of beef are extensively discussed in the review by de Smet et al. (2004). It is possible that the differences in carcass fatness between breeds in the present experiment (carcass fat score 3.2 vs. 2.2 for AA and NR bulls, respectively) affected also the differences in the fatty acid composition of the loin. According to de Smet et al. (2004), carcass fat score affects the fatty acid profile of the meat, and breed differences reported in the literature are often confounded by differences in fatness as in the present experiment. Nevertheless, specific breed differences in the $n-6 / n-3$ fatty acid ratio and in the levels of longer chain fatty acids that probably could not be attributed to differences in the fat level have also been reported (de Smet et al. 2004), but many of these breed differences are relatively small and are, although often statistically significant, probably of little value from a viewpoint of human nutrition.

Replacing GS by the whole crop legume silages had only minor effects on meat quality parameters. There is paucity of published information on the meat quality of growing cattle offered whole crop legume silages instead of grass silage. Keady et al. (2007) concluded that meat quality of beef steers was not altered by the inclusion of whole crop cereal silages in grass silage based diets. In another study, Walsh et al. (2008) observed no differences in muscle colour of finishing steers when comparing grass silage and two different whole crop wheat silage based diets. However, animals offered grass silage had the most yellow fat and those offered urea-treated, processed whole crop wheat had the whitest fat (Walsh et al. 2008). Increased marbling has been associated with improved meat eating quality (e.g. Wheeler et al. 1994). In the present study, the whole crop legume silage based diets tended to increase marbling score compared to GSB but effects on eating quality in sensory analysis were not observed. Feeding treatments had only minor effects on meat fatty acids concentrations and observed effects have little importance from a practical point of view.

\section{Conclusions and implications}

Expected breed differences between the AA and NR bulls in growth and carcass traits were observed when the bulls were slaughtered at the age of 500 days. The AA bulls grew faster, had better feed conversion rates and superior dressing proportion and carcass conformation compared to the NR bulls. In addition, the AA bulls 
A. Huuskonen et al. (2016) 25: 1-12

produced meat with a lower n-6/n-3 fatty acid ratio compared to the NR bulls. Replacing moderately digestible timothy silage by whole crop legume-cereal silages in the diet did not have remarkable effects on animal performance, carcass characteristics or meat quality of the growing bulls. There was no difference in growth performance, carcass characteristics or meat quality when the bulls were fed either faba bean-wheat silage or field pea-wheat silage based diets. However, the total DM and energy intakes were higher in the faba bean-wheat silage diet compared to the field pea-wheat silage based diet. As hypothesized, there were no interactions between silage plant species and breed on growth performance, carcass characteristics and meat quality traits.

Due to environmental aspects and the absence of effects on animal performance, increased forage protein content compared to grass silage is not a sufficient justification for using forage legumes for growing cattle. However, if production costs of whole crop legume-cereal silages are lower than those of grass silage and including them in crop rotation brings benefits, using them may increase the overall profitability of the farm.

\section{Acknowledgements}

This study was partially funded by the Centre for Economic Development, Transport and the Environment for Northern Ostrobothnia. The authors thank Lauri Jauhiainen for advice on statistical analysis. We wish also to express our gratitude to Jarkko Kekkonen and his personnel for technical assistance and their excellent care of the experimental animals. The evaluation of the manuscript by Professor Marketta Rinne is warmly acknowledged.

\section{References}

Ahvenjärvi, S., Joki-Tokola, E., Vanhatalo, A., Jaakkola, S. \& Huhtanen, P. 2006. Effects of replacing grass silage with barley silage in dairy cow diets. Journal of Dairy Science 89: 1678-1687.

Alberti, P., Panea, B., Sañudo, C., Olleta, J.L., Ripoll, G., Ertbjerg, P., Christensen, M., Gigli, S., Failla, S., Concetti, S., Hocquette, J.F., Jailler, R., Rudel, S., Renend, G., Nute, G.R., Richardson, R.I. \& Williams, J.L. 2008. Live weight, body size and carcass characteristics of young bulls of fifteen European breeds. Livestock Science 114: 19-30.

Anil, L., Park, J., Phipps, R.H. \& Miller, F.A. 1998. Temperate intercropping of cereals for forage: a review of the potential for growth and utilization with particular reference to the UK. Grass and Forage Science 53: 301-317.

CEC 1999. Council regulation No 1804/1999 supplementing regulation No 2092/91 on organic production. Official Journal of the European Communities L222: 1-28.

Cummins, B., Keane, M.G., O'Kiely, P. \& Kenny, D.A. 2007. Effects of breed type, silage harvest date and pattern of offering concentrates on intake, performance and carcass traits of finishing steers. Irish Journal of Agricultural and Food Research 46: 149-168.

De Smet, S., Raes, K. \& Demeyer, D. 2004. Meat fatty acid composition as affected by fatness and genetic factors: a review. Animal Research 53: 81-98.

DeVries, T. J., von Keyserlingk, M.A.G., Weary, D.M. \& Beauchemin, K.A. 2003. Technical note: Validation of a system for monitoring feeding behavior of dairy cows. Journal of Dairy Science 86: 3571-3574.

EC 2006. Council Regulation (EC) No 1183/2006 of 24 July 2006 concerning the Community scale for the classification of carcasses of adult bovine animals. The Official Journal of the European Union L214: 1-6.

Elmore, J.S. Warren, H.E., Mottram, D.S., Scollan, N.D., Enser, M., Richardson, R.I. \&Wood, J.D. 2004. A comparison of the aroma volatiles and fatty acid compositions of grilled beef muscle from Aberdeen Angus and Holstein-Friesian steers fed diets based on silage or concentrates. Meat Science 68: 27-33.

Huhtanen, P., Nousiainen, J. \& Rinne, M. 2006. Recent developments in forage evaluation with special reference to practical applications. Agricultural and Food Science 15: 293-323.

Huhtanen, P., Rinne, M. \& Nousiainen, J. 2007. Evaluation of the factors affecting silage intake of dairy cows; a revision of the relative silage dry matter intake index. Animal 1: 758-770.

Huida, L., Väätäinen, H. \& Lampila, M. 1986. Comparison of dry matter contents in grass silage as determined by oven drying and gas chromatographic water analysis. Annales Agriculturae Fenniae 25: 215-230.

Huuskonen, A. 2013. Performance of growing and finishing dairy bulls offered diets based on whole-crop barley silage with or without protein supplementation relative to a grass silage-based diet. Agricultural and Food Science 22: 424-434.

Huuskonen, A. 2014. A comparison of Nordic Red, Holstein-Friesian and Finnish native cattle bulls for beef production and carcass traits. Agricultural and Food Science 23: 159-164.

Huuskonen, A., Huhtanen, P. \& Joki-Tokola, E. 2013a. The development of a model to predict feed intake by growing cattle. Livestock Science 158: 74-83.

Huuskonen, A., Huhtanen, P. \& Joki-Tokola, E. 2014b. Evaluation of protein supplementation for growing cattle fed grass silagebased diets: a meta-analysis. Animal 8: 1653-1662.

Huuskonen, A. \& Joki-Tokola, E. 2010. Performance of growing dairy bulls offered diets based on silages made of whole-crop barley, whole-crop wheat, hairy vetch and grass. Agricultural and Food Science 19: 116-126. 
A. Huuskonen et al. (2016) 25: 1-12

Huuskonen, A., Khalili, H. \& Joki-Tokola, E. 2008. Inclusion of barley fibre and barley protein in a total mixed ration for growing dairy bulls. Acta Agriculturae Scandinaciva, Section A, Animal Science 58: 37-44.

Huuskonen, A., Pesonen, M. \& Joki-Tokola, E. 2014a. Effects of supplementary concentrate level and separate or total mixed ration feeding on performance of growing dairy bulls. Agricultural and Food Science 23: 257-265.

Huuskonen, A., Pesonen, M., Kämäräinen, H. \& Kauppinen, R. 2013b. A comparison of purebred Holstein-Friesian and HolsteinFriesian $\times$ beef breed bulls for beef production and carcass traits. Agricultural and Food Science 22: 262-271.

Keady, T.W.J., Hanrahan, J.P., Marley, C.L. \& Scollan, N.D. 2013. Production and utilization of ensiled forages by beef cattle, dairy cows, pregnant ewes and finishing lambs: a review. Agricultural and Food Science 22: 70-92.

Keady, T.W.J., Lively, F.O., Kilpatrick, D.J. \& Moss, B.W. 2007. Effects of replacing grass silage with either maize or whole-crop wheat silages on the performance and meat quality of beef cattle offered two levels of concentrates. Animal 1: 613-623.

Keane, M.G. \& Allen, P. 1998. Effects of production system intensity on performance, carcass composition and meat quality of beef cattle. Livestock Production Science 56: 203-214.

Keane, M.G. \& Allen, P. 2002. A comparison of Friesian-Holstein, Piemontese $\times$ Friesian-Holstein and Romagnola $\times$ Friesian-Holstein steers for beef production and carcass traits. Livestock Production Science 78: 143-158.

Kempster A.J., Cook G.L. \& Southgate J.R. 1988. Evaluation of British Friesian, Canadian Holstein and beef breed $\times$ British Friesian steers slaughtered over a commercial range of fatness from 16-month and 24-month beef production systems. 2. Carcass characteristics, and rate and efficiency of lean gain. Animal Production 46: 365-378.

Luke 2015. Feed tables and nutrient requirements. http://www.luke.fi/feedtables. Cited 25.6.2015.

MAFF 1984. Energy Allowances and Feeding Systems for Ruminants. ADAS Reference book 433. Ministry of Agriculture, Fisheries and Food. Her Majesty`s Stationery Office, London. 85 p.

Mendes, E.D.M., Carstens, G.E., Tedeschi, L.O.Pinchak, W.E. \& Friend, T.H. 2011. Validation of a system for monitoring feeding behavior in beef cattle. Journal of Animal Science 89: 2904-2910.

Moisio, T. \& Heikonen, M. 1989. A titration method for silage assessment. Animal Feed Science and Technology 22: 341-353.

More O'Ferrall, G.J. \& Keane, M.G. 1990. A comparison for live weight and carcass production of Charolais, Hereford and Friesian steer progeny from Friesian cows finished on two energy levels and serially slaughtered. Animal Production 50: 19-28.

Niemi, J. \& Ahlstedt, J. 2014. Finnish agriculture and rural industries 2014. MTT Agrifood Research Finland, Economic Research, Helsinki, Finland. Publications 115a. 97 p.

Pesonen, M., Honkavaara, M. \& Huuskonen, A. 2012. Effect of breed on production, carcass traits and meat quality of Aberdeen Angus, Limousin and Aberdeen Angus $\times$ Limousin bulls offered a grass silage-grain-based diet. Agricultural and Food Science 21: 361-369.

Pesonen, M., Honkavaara, M., Kämäräinen, H., Tolonen, T., Jaakkola, M., Virtanen, V. \& Huuskonen, A. 2013. Effects of concentrate level and rapeseed meal supplementation on performance, carcass characteristics, meat quality and valuable cuts of Hereford and Charolais bulls offered grass silage-barley-based rations. Agricultural and Food Science 22: 151-167.

Pesonen, M. \& Huuskonen, A. 2015. Production, carcass characteristics and valuable cuts of beef breed bulls and heifers in Finnish beef cattle population. Agricultural and Food Science 24: 164-172.

Pesonen, M., Joki-Tokola, E. \& Huuskonen, A. 2014. Effects of concentrate proportion and protein supplementation on performance of growing and finishing crossbred bulls fed a whole-crop barley silage-based diet. Animal Production Science 54: 1399-1404.

Pfuhl, R., Bellmann, O., Kühn, C., Teuscher, F., Ender, K. \& Wegner, J. 2007. Beef versus dairy cattle: a comparison of feed conversion, carcass composition, and meat quality. Archiv Tierzucht, Dummerstorf 50: 59-70.

Phelan, P., Moloney, A.P., McGeough, E.J., Humphreys, J., Bertilsson, J., O’Riordan, E.G. \& O’Kiely, P. 2015. Forage legumes for grazing and conserving in ruminant production systems. Critical Reviews in Plant Sciences 34: 281-326.

Phillips, C.J.C. 2010. Principles of cattle production. $2^{\text {nd }}$ Edition. CABI Publications, Cambridge University Press, Cambridge, UK. 233 p.

Rustas, B.-O. 2009. Whole-crop cereals for growing cattle. Effects of maturity stage and chopping on intake and utilisation. Doctoral Thesis. Swedish University of Agricultural Sciences, Skara, Sweden. 60 p.

Shingfield, K. J., Ahvenjärvi, S., Toivonen, V., Ärölä, A., Nurmela, K. V. V., Huhtanen, P. \& Griinari, J. M. 2003. Effect of dietary fish oil on biohydrogenation of fatty acids and milk fatty acid content in cows. Animal Science 77: 165-179.

Sinclair, L. A., Wilkinson, R.G. \& Ferguson, D.M.R. 2003. Effects of crop maturity and cutting height on the nutritive value of fermented whole crop wheat and milk production in dairy cows. Livestock Production Science 81: 257-269.

Strydhorst, S.M., King, J.R., Lopetinsky, K.J. \& Harker, K.N. 2008. Forage potential of intercropping barley with faba bean, lupin and field pea. Agronomy Journal 100: 182-190.

Van Soest, P.J., Robertson, J.B. \& Lewis, B.A. 1991. Methods for dietary fiber, neutral detergent fiber, and nonstarch polysaccharides in relation to animal nutrition. Journal of Dairy Science 74: 3583-3597.

Wallsten, J. 2008. Whole-crop cereals in dairy production. Digestibility, feed intake and milk production. Doctoral Thesis. Swedish University of Agricultural Sciences, Umeå, Sweden. 45 p.

Walsh, K., O'Kiely, P., Moloney, A.P. \& Boland, T.M. 2008. Intake, performance and carcass characteristics of beef cattle offered diets based on whole-crop wheat or forage maize relative to grass silage or ad libitum concentrates. Livestock Science 116: 223-236.

Wheeler, T.L., Cundiff, L.V. \& Koch, K.M. 1994. Effect of marbling degree on beef palatability in Bos taurus and Bos indicus cattle. Journal of Animal Science 72: 3145-3153.

Willey, R.W. 1979. Intercropping - its importance and research needs. Part I - Competition and yield advantages. Field Crop Abstracts 32: 1-10.

Zaralis, K., Nørgaard, P., Helander, C., Murphy, M., Weisbjerg, M.R. \& Nadeau, E. 2014. Effects of maize maturity at harvest and dietary proportion of maize silage on intake and performance of growing/finishing bulls. Livestock Science 168: 89-93. 